\title{
HUBUNGAN PAPARAN MEDIA SOSIAL (INSTAGRAM) DENGAN PERILAKU SEKS BEBAS PADA REMAJA DI SMA NEGERI 5 SAMARINDA
}

\author{
Yuliani Winarti*, Monica Andriani* \\ Email: yw399@umkt.ac.id
}

\begin{abstract}
ABSTRAK
Instagram di masa sekarang menjadi rutinitas setiap hari para remaja. Instagram adalah media yang membuat pengguna terhubung dengan orang-orang yang ada diseluruh dunia. karena itu dampak yang didapatkan remaja pada masa sekarang tentunya lebih beresiko menyebabkan perilaku seks bebas. Tujuan penelitian ini untuk mengetahui hubungan paparan media sosial (Instagram) dengan perilaku seks bebas pada remaja di SMA Negeri 5 Samarinda. Penelitian ini merupakan penelitian kuantitatif dengan desain penelitian cross sectional.

Jenis penelitian ini merupakan survei analitik dengan pendekatan studi "Cross Sectional". Penelitian ini dilakukan pada bulan Mei 2019. Jumlah sampel sebanyak 75 responden yang didapatkan menggunakan tekhnik stratified random sampling. Pengumpulan data menggunakan kuesioner dan analisis data menggunakan statistik Chi Square (derajat kemaknaan 95\%).

Hasil penelitian didapatkan hasil ada hubungan antara paparan media sosial (instagram) dengan perilaku seks pranikah ( $p$ 0.027). Disimpulkan bahwa ada hubungan yang signifikan antara paparan media sosial (Instagram) dengan perilaku seks bebas pada remaja di SMA Negeri 5 Samarinda.
\end{abstract}

Kata Kunci : media sosial (Instagram), perilaku seks bebas, remaja

\section{ABSTRACT}

The use of Instagram at the present time is one part of the daily activities of teenagers. Instagram it self is a media that connects users with people around the world. therefore the impact that adolescents have on the present is certainly more at risk of causing free sex. Purpose of Research: this study aims to determine the relationship between the social media exposure (Instagram) and free sex behavior in adolescents in SMA 5 Samarinda 2019.

This research is a quantitative research with cross sectional research design. The number of samples is 75 respondents selected using stratified random sampling. Collecting data are using questionnaire and data analysis used Chi Square test.

The result showed there is relationship between exposure to social media (Instagram ) with free sex in adolescents in SMA Negeri 5 Samarinda ( $p$-value is 0.027). There is relationship between exposure to social media (Instagram ) with free sex in adolescents in SMA Negeri 5 Samarinda.

Key words : social media (Instagram), free sex, adolescent

\section{PENDAHULUAN}

Perilaku seks bebas ialah suatu tingkah laku yang didorong oleh hasrat seksual, baik dengan lawan jenisnya maupun dengan sesama jenisnya. Bentuk-bentuk tingkah laku ini biasanya bermacam-macam, mulai dari perasaan tertarik hingga tingkah laku berkencan, bersenggama dan bercumbu.
Perilaku seksual membuat rangsangan hormon semata, melainkan digambarkan pengaruh antara pikiran dan hormon ${ }^{[1]}$. Salah satu penyebab perilaku seks bebas diantaranya dari penggunaan media sosial yang kini banyak digunakan remaja-remaja di jaman sekarang. Pengguna instagramsekarang menjadi salah satu kegiatan sehari-hari remaja.

*. Fakultas Kesehatan dan Farmasi Universitas Muhammadiyah Kalimantan Timur 
Instagram merupakan media yang menghubungkan pengguna dengan orang-orang di seluruh dunia. karena itu dampak yang didapat remaja pada masa sekarang tentunya lebih beresiko menyebabkan perilaku seks bebas. Para remaja sekarang mengharuskan memiliki instagram agar mereka mudah berkomunikasi dan mengetahui remaja mengunggah foto/video pribadi mereka ke media sosial instagram agar dilihat oleh pengikut mereka di instagram.

Survei dari beberapa negara berkembang tahun 2017 bahwa di negara Liberia, yaitu remaja putri menunjukkan $46 \%$ usia 14-17 tahun dan $66.2 \%$ remaja putra sudah saling bersenggama. Di Nigeria 38\% remaja putri dan $57.3 \%$ remaja putra usia $15-$ 19 tahun sudah bersenggama [3]. Di Indonesia memiliki jumlah penduduk yang memiliki remaja sebesar 42,4 juta berdasarkan data yang dimiliki Badan Pusat Statistik Indonesia. Menurut Komnas Perlindungan Anak (KPAI) dan Kementerian Kesehatan menyatakan bahwa hasil survei menunjukkan sebuah data yaitu $62,7 \%$ di Indonesia remaja pernah melakukan hubungan seks bebas atau seks diluar pranikah ${ }^{[4]}$.

Diketahui bahwa di Kecamatan Samarinda Ulu terdapat angka tertinggi HIV/AIDS, sehingga pemilihan lokasi juga berada di Kecamatan Samarinda Ulu yaitu di sekolah SMA Negeri 5 Samarinda dengan jumlah 1.047 siswa/I. Berdasarkan hasil studi pendahuluan dengan melakukan wawancara kepada siswa/I sebanyak 17 responden, 11 responden mengatakan pernah melakukan pegangan tangan, berpelukan dan salah satu pasangan yang berpacaran pernah melakukan ciuman didalam kelas. Serta adanya fasilitas yang dimiliki sekolah ini yaitu tersedianya wifi yang dapat digunakan oleh siswa/i serta bebas diperbolehkan menggunakan handphone kecuali pada saat proses belajar berlangsung. Akibat adanya fasilitas di sekolah mereka bisa mengakses media sosial, salah satunya mengakses media sosial instagram yang responden gunakan setiap hari. Tujuan dari penelitian ini yaitu untuk mengetahui hubungan paparan media sosial (Instagram) dengan perilaku seks bebas pada remaja di SMA Negeri 5 Samarinda.

\section{METODE PENELITIAN}

Penelitian ini menggunakan rancangan penelitian kuantitatif, dengan desain cross sectional yang menekankan pada dinamika korelasi antar faktorfaktor dengan efek melalui cara pendekatan,observasi atau pengumpulan data sekaligus ${ }^{[4]}$. Pengujian hipotesis ini berdasarkan taraf signifikan $5 \%$ atau $p$ value $=0.05$. Populasi dalam penelitian ini adalah seluruh siswa(i) kelas XI SMA Negeri 5 Samarinda yaitu 359 siswa/I dan perhitungan secara stratified sampling dari total populasi tersebut berjumlah 75 responden. Responden penelitian ini telah termasuk dalam kriteria inklusi yaitu, siswa/I kelas XI yang bersekolah di SMA Negeri 5 Samarinda dan bersedia menjadi responden penelitian.

Dari sumber data penelitian ini yaitu data primer dan data sekunder. Data primer merupakan sumber data yang langsung memberikan datanya pada pengumpul data. Data sekunder diperoleh oleh Komisi Penanggulangan AIDS Kota Samarinda mengenai seks bebas serta diperoleh dari berbagai sumber dari literatur dan buku-buku ${ }^{[17]}$. Instrumen penelitian ini menggununakan kuesioner secara tertutup yaitu teknik pengumpulan data yang di lakukan peneliti dengan memberi seperangkat pernyataan tertulis untuk dijawab oleh responden.

Pengumpulan data dalam penelitian ini menggunakan instrumen kuesioner dengan teknik uji validitas menggunakan Point-Biseral dengan hasil valid 11 item masing-masing skor Rpbis $\geq 0,03^{[15]}$ dan yang tidak valid dengan skor $\leq 0,3$ yaitu pertanyaan nomor 8 , 12,14 dan 15. Adapun hasil reliabilitas menggunakan KR $21 \mathrm{a}=0,916$. Variabel dependent tentang perilaku seks bebas terdiri dari 2 kategori yaitu sedang (berpegang tangan, berpelukan dan mencium) dan berat (telah melakukan semua perilaku seks bebas sedang dan melakukan: meraba, petting,oral seks, hingga sexual intercourse (hubungan seksual)), serta variabel independent tentang media sosial (Instagram) yang 
memiliki 2 kategori yaitu sering (skor nilai $>5$ ) dan jarang (skor nilai $<5$ ).

Uji statistik yang di gunakan dalam penelitian ini ialah Uji Chi Square dan memenuhi syarat dengan menggunakan uji Continuity Correction. Setelah dilakukan uji Continuity Correction memperoleh nilai $p$-value sebesar 0.036 nilai ini lebih kecil dari taraf signifikan a yaitu 0.05 sehingga dapat disimpulkan bahwa terdapat hubungan signifikan antara paparan media sosial (Instagram) dengan perilaku seks bebas pada remaja di SMA Negeri 5 Samarinda.

\section{HASIL}

\section{Analisis Univariat}

Karakteristik Responden Berdasarkan Usia dan Jenis Kelamin

Tabel 1

Distribusi Responden Berdasarkan Usia dan Jenis Kelamin

\begin{tabular}{lcc}
\hline Kategori & Jumlah & $\begin{array}{c}\text { Persentase } \\
(\%)\end{array}$ \\
\hline Usia (tahun): & 2 & 2.7 \\
14 & 22 & 29.3 \\
15 & 42 & 56 \\
16 & 6 & 8 \\
17 & 3 & 4 \\
18 & & \\
Jenis kelamin: & & 60 \\
Perempuan & 45 & 40 \\
Laki-laki & 30 & \\
n=75 & &
\end{tabular}

Berdasarkan tabel

menunjukkan sebagian besar responden dengan presentase (56\%) pada usia 16 tahun dan terendah dengan presentase $(2.7 \%)$ pada usia 14 tahun. Kategori usia termuda pada 75 responden dengan presentase $(2.7 \%)$ usia 14 tahun dan presentase (4\%) usia tertua 18 tahun. Sedangakan berdasarkan karakteristik jenis kelamin menunjukkan bahwa sebagian besar responden sebanyak 45 responden berjenis kelamin perempuan dengan presentase $(60 \%)$ dan sebanyak
30 responden berjenis kelamin laki-laki dengan presentase (40\%).

Paparan Media Sosial (Instagram) Terkait Perilaku Seks Bebas

Tabel 2

Paparan Media Sosial (Instagram) dan Seks Bebas

\begin{tabular}{|c|c|c|}
\hline \multirow{2}{*}{ Variabel } & \multicolumn{2}{|c|}{ Total } \\
\hline & $\mathbf{N}$ & $\%$ \\
\hline $\begin{array}{l}\text { Media } \\
\text { (Instagram): Sosial }\end{array}$ & & \\
\hline Jarang & 41 & 54.7 \\
\hline Sering & 34 & 45.3 \\
\hline Perilaku Seks Bebas : & & \\
\hline $\begin{array}{l}\text { Sedang } \\
\text { Berat }\end{array}$ & $\begin{array}{l}62 \\
13\end{array}$ & $\begin{array}{l}82.7 \\
17.3\end{array}$ \\
\hline
\end{tabular}

Berdasarkan tabel 2 menunjukkan paparan media sosial (Instagram) terkait perilaku seks bebas yang memiliki 2 kategori yaitu jarang, dan sering. dengan presentase $(54.7 \%)$ terdapat 41 responden jarang menggunakan media sosial (Instagram) untuk mengakses dan menonton terkait konten pornografi, dan dengan presentase $(45.3 \%)$ terdapat 34 responden kategori sering dalam penggunaan media sosial (Instagram) untuk menonton atau mengakses terkait konten pornografi. Sedangkan berdasarkan perilaku responden dalam perilaku seks bebas yang memiliki 2 kategori yaitu perilaku seks bebas sedang dan perilaku seks bebas berat. Dengan presentase $(82.7 \%)$ terdapat 62 responden yang berperilaku seks bebasnya sedang dan dengan presentase (17.3\%) 13 responden yang berperilaku seks bebasnya berat.

\section{Analisis Bivariat}

Analisi bivariat pada paparan media sosial (Instagram) dengan perilaku perilaku seks bebas pada remaja di SMA Negeri 5 Samarinda diantaranya : 
Tabel 3

Paparan Media Sosial (Instagram) dengan Perilaku Seks Bebas Pada Remaja Di SMA Negeri 5 Samarinda

\begin{tabular}{|c|c|c|c|c|c|c|c|c|}
\hline \multicolumn{2}{|l|}{ Variabel } & \multicolumn{2}{|c|}{$\begin{array}{c}\text { Perilaku Seks } \\
\text { Bebas }\end{array}$} & \multirow[t]{2}{*}{$\mathbf{N}$} & \multirow{2}{*}{$\begin{array}{c}\text { p- } \\
\text { value }^{n}\end{array}$} & \multirow[t]{2}{*}{ OR } & \multicolumn{2}{|c|}{ CI 95\% } \\
\hline & & Berat & Sedang & & & & Lower & Upper \\
\hline $\begin{array}{l}\text { Media Sosial } \\
\text { (Instagram) }\end{array}$ & Sering & $\begin{array}{c}10 \\
(13.4 \%)\end{array}$ & $\begin{array}{c}24 \\
(32 \%)\end{array}$ & $\begin{array}{c}34 \\
(45.3 \%)\end{array}$ & \multirow{2}{*}{0.027} & \multirow{2}{*}{5.278} & \multirow{2}{*}{1.318} & \multirow{2}{*}{21.141} \\
\hline & Jarang & $\begin{array}{c}3 \\
(4 \%)\end{array}$ & $\begin{array}{c}38 \\
(50.7 \%)\end{array}$ & $\begin{array}{c}41 \\
(54.7 \%)\end{array}$ & & & & \\
\hline
\end{tabular}

Berdasarkan

tabel 3 menunjukkan bahwa responden yang menggunakan media sosial (Instagram) berada pada kategori sering namun berperilaku seks bebas berat yaitu 10 responden dengan persentase $13.4 \%$ dan sering namun berperilaku sedang yaitu 24 responden dengan persentase $32 \%$, sedangkan responden yang menggunakan media sosial (Instagram) berada pada kategori jarang namun berprilaku sedang yaitu 3 responden dengan persentase $4 \%$ dan jarang namun berperilaku sedang yaitu 38 responden dengan persentase $50.7 \%$.

Hasil uji chi-square yang telah dilakukan memperoleh nilai $p$-value sebesar 0.027 dimana nilai tersebut lebih kecil dari taraf signifikan a yaitu 0.05 sehingga dapat disimpulkan bahwa terdapat hubungan signifikan antara paparan media sosial (Instagram) dengan perilaku seks bebas pada remaja di SMA Negeri 5 Samarinda.

Nilai OR (Odds Ratio) menunjukkan hasil yaitu 5.278 yang artinya tidak terdapat upaya pencegahan pada media internet dengan perilaku seks bebas. Nilai CI (95\% Confidence Interval) yaitu 1.318-21.141, hasil menunjukkan bahwa nilai $\mathrm{CI}>1$ sehingga hasil tidak protektif atau bisa dikatakan tidak terdapat sifat pencegahan terhadap paparan media sosial (Instagram) dengan perilaku seks bebas pada remaja di SMA Negeri 5 Samarinda.

\section{PEMBAHASAN}

\section{Karakteristik \\ Berdasarkan Usia dan Jenis Kelamin}

Dari hasil perhitungan

karakteristik dapat dilihat bahwa dari total 75 responden dengan kategori umur 14-18 tahun lebih banyak usia 15 tahun dengan persentase sebesar $29.3 \%$, sedangkan pada karakteristik kategori jenis kelamin dengan persentase $60 \%$ terbanyak pada kategori jenis kelamin perempuan.

Perkembangan remaja yaitu remaja awal (11-13) tahun, pada remaja awal seorang remaja memiliki sebuah pikiran-pikiran yang baru diantaranya rasa cepat tertarik pada lawan jenis, remaja menengah (14-16 tahun) pada masa remaja ini seorang remaja mulai memiliki perkembangan pola fikir yang tinggi, dimana bila ia digemari oleh temannya ia akan merasa senang dan bangga. Remaja akhir (17-20 tahun), pada fase ini remaja mulai mempersiapkan peran sebagai orang dewasa, dimana remaja berusaha menyatu dengan orang lain dan mencari pengalaman baru dan adanya perubahan sikap diri ${ }^{[6]}$. Remaja yang usianya lebih tua maka kecenderungan lebih besar perilaku seksual pranikah. Hal ini dikarenakan pasangan yang usianya lebih tua memiliki pengalaman dalam berperilaku seksual sehingga remaja yang memiliki pasangan dengan usia lebih tua maka dalam melakukan hubungan seks bebas lebih besar dari pada seusianya ${ }^{[16]}$.

\section{Paparan Media Sosial (Instagram)}

Berdasarkan tabel 2

menunjukkan paparan media sosial (Instagram) terkait perilaku seks bebas yang memiliki 2 kategori yaitu jarang, dan sering. dengan presentase $(54.7 \%)$ terdapat 41 responden jarang menggunakan media sosial (Instagram) untuk mengakses dan menonton terkait konten pornografi, dan dengan presentase $(45.3 \%)$ terdapat 34 responden kategori sering dalam 
penggunaan media sosial (Instagram) untuk menonton atau mengakses terkait konten pornografi.

Media sosial (Instagram) ini menjadikan remaja menjadi terbuka terhadap dirinya di depan orang lain ataupun dengan seseorang yang belum dikenal sebelumnya. Kecangihan smartphone yang mendukung kebebasan bermedia sosial dan provider yang menyediakan tarif layanan yang murah untuk mengakses media sosial terutama (Instagram). Hal inilah yang mendorong remaja melupakan batasan-batasan yang seharusnya mereka tidak ketahui $^{[7]}$.

Instragram merupakan suatu media atau alat komunikasi yang digunakan oleh seseorang untuk berinteraksi dan berkomunikasi tanpa adanya hambatan seperti batasan usia, jenis kelamin, jenis pekerjaan dan batasan negara. Hal ini yang menjadi ketertarikan remaja dalam menggunakan media sosial (Instagram) karena tidak ada batasan dengan apapun berdasarkan penelitian ${ }^{[15] \text {. }}$

\section{Perilaku Seks Bebas}

Kategori perilaku seks bebas dalam penelitian ini ada 2 yaitu sedang (berpegangan tangan, berpelukan dan mencium) dan berat (yaitu telah melakukan semua perilaku seks bebas ringan dan melakukan : meraba, petting, oral seks, hingga sexual intercourse (hubungan seksual)). Sehingga dari kategori tersebut bisa diketahui apakah responden memiliki perilaku seks bebas yang sedang atau berat.

Berdasarkan perilaku responden dalam perilaku seks bebas yang memiliki 2 kategori yaitu perilaku seks bebas sedang dan perilaku seks bebas berat. Dengan presentase $(82.7 \%)$ terdapat 62 responden yang berperilaku seks bebasnya sedang dan dengan presentase $(17.3 \%) 13$ responden yang berperilaku seks bebasnya berat.

Perilaku seksual remaja sekarang cukup mencemaskan pengetahuan remaja tentang kesehatan reproduksi yang kurang ternyata berpengaruh terhadap remaja untuk melakukan hubungan seksual pranikah yang mengetahui ataupun yang tidak mengetahui tentang kesehatan reproduksi, oleh karena itu paparan media masa, baik dari cetak maupun media sosial sangat berpengaruh secara langsung dan tidak langsung kepada remaja untuk melakukan hubungan perilaku seks bebas ${ }^{[8]}$.

\section{Paparan Media Sosial (Instagram) Dengan Perilaku Seks Bebas Remaja \\ Penelitian ini dilakukan dan} menggunakan uji chi-square yang telah dilakukan memperoleh nilai $p$-value yaitu sebesar 0.027 dimana nilai tersebut lebih kecil dari taraf signifikan a yaitu 0.05 sehingga dapat disimpulkan bahwa terdapat hubungan signifikan antara paparan media elektronik dengan perilaku seks bebas pada remaja di SMA Negeri 5 Samarinda. Berdasarkan nilai $p$ value yaitu 0.027 dimana dapat diketahui bahwa hubungan paparan media sosial (Instagram) dengan perilaku seks bebas pada remaja di SMA Negeri 5 Samarinda sangat kuat.

Dari hasil penelitian yang dilakukan sebelumnya oleh Levi Tina Sari (2019) dijelaskan bahwa Instagrambanyak di gunakan oleh masyarakat khusunya remaja di karenakan penggunaanya lebih mudah, serta penggunaan Instagramdapat mewakili media sosial lainnya karena memiliki fiturfitur lengkap dan menarik didalamnya.Media sosial (Instagram) memiliki banyak memiliki konten-konten pornografi yang mudahdiakses, sesuai dengan pernyataan responden saat observasi bahwa pengguna instagram dapat dengan mudah melihat kontenkonten porno tanpa harus berteman atau masuk kedalam grup ${ }^{[16]}$.

Informasi yang cepat dan mudah beredar membuat kurangnya batasan mengenai konten-konten yang dapat diakses oleh penggunanya. Terdapat lebih dari satu juta konten porno yang tersebar di Instagram. Dengan melakukan pencarian menggunakan hashtag, gambar serta video berkonten porno dapat diakses secara langsung. Bahkan tanpa mencarinya, gambar ini akan tersedia dalam explore apabila akun yang di follow mengakses gambar atau video berkonten porno. Dapat diketahui dari pengguna Instagram didominasi oleh kalangan remaja usia 16-19 tahun $^{[8]}$. 
Pencegahan seks bebas menurut Handoyo (2010) Pendidikan seks adalah membimbing serta mengasuh seorang agar dapat mengerti tentang arti, fungsi dan tujuan seks, salah satu cara untuk mengurangi atau mencegah penyalahgunaan seks. Media massa sangat berperan penting dalam perubahan pola tingkah laku dari suatu masyarakat terutama remaja, oleh karena itu pengaruh media massa dalam masyarakat sangat penting terutama bagi remaja yang keingintahuannya tinggi salah satu media massa yang paling diminati adalah instagram.

Berdasarkan hasil wawancara dan observasi di SMA Negeri 5 Samarinda bahwa tidak adanya media massa yang menyebarluaskan tentang informasi perilaku seks bebas dilingkuangan sekolah dan diperbolehkannya siswa/I menggunakan handphone dilingkungan sekolah kecuali pada saat proses belajar berlangsung sehingga tidak ada batasan bagi siswa/I untuk mengakses media sosial (Instagram).

\section{SIMPULAN}

Hasil uji Continuty Correction yang telah dilakukan memperoleh nilai $p$-value yang dilihat yaitu sebesar 0.027 dimana nilai tersebut lebih kecil dari taraf signifikan a yaitu 0.05 sehingga dapat disimpulkan bahwa terdapat hubungan signifikan antara paparan media sosial (Instagram) dengan perilaku seks bebas pada remaja SMA Negeri 5 Samarinda.

\section{SARAN}

Bagi sekolah SMA Negeri 5 Samarinda sebaiknya ada kebijakan larangan membawa handphone di sekolah guna meminimalisir terjadinya penyalahgunaan media tersebut ke halhal negatif. Namun, karena penggunaan handphone diperbolehkan maka sebaiknya siswa/I bisa menggunakannya pada hal yang positif seperti menggunakan media sosial namun mengakses informasi-informasi yang bermanfaat seperti mengikuti akun kemenkes_ri yang berisikan informasi kesehatan bagi semua kalagan masyarakat.
Bagi Orang tua sebaiknya lebih memperhatikan kegiatan yang dilakukan oleh anaknya, seperti memberikan batasan dan pengawasan dalam menggunakan handphone dan jejaring sosial yang di berikan kepada anak. selain itu diharapkan orang tua menjalin komunikasi yang baik kepada anak agar adanya keterbukaan antara orang tua dan anak. Orang tua juga sebaiknya memberikan edukasi tentang kesehatan reproduksi agar anak tahu dan tidak melakukan hal-hal diluar batas.

Bagi remaja khususnya siswa/I SMA Negeri 5 Samarinda sebaiknya mengetahui tentangpendidikan seksual yang benar, menambahkan pengetahuan agar memanfaatkan media sosial (Instagram) sebagai sumber informasi yang benar.dan tidak menggunakan fasilitasmaupun media sosial (Instagram) yang dimiliki untuk hal-hal yang berbau pornografi . Selain ituremaja sebaiknyamenggunakan media sosial untuk hal-hal yang lebih positif, menjual barang online melalui instagram, membagikan informasi tentang kesehatan atau hal lainnya dan lain-lain.

\section{DAFTAR PUSTAKA}

Depkes RI. (2012). Situasi HIV/AIDS di Indonesia.

Erna Dusra. (2017). Pengaruh Media Internet Terhadap Perilaku Menyimpang Remaja di Sekolah Menengah Atas Negeri 1 Maros pp. 1-157, 2017.

F. Kasim. (2014). Dampak Perilaku Seks Berisiko terhadap Kesehatan Reproduksi dan Upaya Penanganannya (Studi tentang Perilaku Seks Berisiko pada Usia Muda di Aceh), J. Stud. Pemuda, vol. 3, no. 1, pp. 39-48.

Hanjani. (2000). Peningkatan Kebutuhan akan Media Sosial Pada Remaja.

H. Indrijati. (2017). Penggunaan internet dan perilaku seksual pranikah remaja, no. 17 , pp. 44-51.

Levi Tina Sari. (2019). Perbedaan Penggunaan Facebook dan Instagram terhadap Perilaku Seks Bebas Remaja Usia 15-17 Tahun, vol. 6, no. 1, pp. 093-100.

Nasrullah, Rulli. 2015. Media Sosial, Bandung: PT Remaja Rosdakarya. 
Notoatmodjo, S. (2005). Metodologi Penelitian Kesehatan. Jakarta: Rineka cipta.

Notoatmodjo, S. (2010). Tumbuh Kembang Remaja dan Permasalahannya. Jakarta: PT Rireka.

Ririn Darmasih. (2012). Faktor yang Mempengaruhi Perilaku Seks Pranikah pada Remaja SMA di Surakarta.

Rivers, Wiliam, dkk. (2004). Media Massa dan Masyarakat Modern. Prenada Media.

Santrock, J.W. (2007). Remaja. Edisi XI
Jakarta: Erlangga.

Sarlito Wirawan Sarwono. (2012). Psikologi Remaja. Jakarta: PT. Raja Grafindo Persada.

Sugiyono. (2009). Metodologi Penelitian Kuantitatif, Kualitatif, dan R\&D. Bandung : Alfabeta.

Vanoss Marin B. (2000). Older Boyfriend and Girlfriends Increase Risk of Sexual Initiation in Young Adolescents. Journal of Adolescent Health, 27, 409-418.

World Health Organization (WHO), (2014). 